Chemical Compositions of Essential Oil and Crude Oil of Some Fruits belonging to Umbelliferae Family cultivated in Konya Ecological Conditions

\author{
Sadiye Ayşe ÇELİK ${ }^{1}$, İrem AYRAN² \\ Selçuk Üniversitesi Ziraat Fakültesi Tarla Bitkileri Bölümü Tıbbi Bitkiler Anabilim Dalı Kampüs/KONYA \\ ${ }^{1}$ https://orcid.org/0000-0002-0765-645X, ${ }^{2}$ https://orcid.org/0000-0002-8005-8231. \\ $凶:$ sacelik@selcuk.edu.tr
}

\section{ABSTRACT}

Apiaceae, also called Umbelliferae, the parsley family, in the order Apiales, comprising around 300 and 400 genera of plants distributed throughout a wide variety of habitats, principally in the north temperate regions of the world. Most members of Umbelliferae family are aromatic herbs. Species used as herbs and spices include fennel (Foeniculum vulgare), anise (Pimpinella anisum), dill (Anethum graveolens), coriander (Coriandrum sativum), and cumin (Cuminum cyminum). In this study, essential oil and crude oil components were determined in the seeds of dill, fennel, aniseed, cumin and coriander. The yield and components of essential oil and crude oil, main active compounds in the fruit of the plants of dill, fennel, anise, cumin and coriander grown in the ecological conditions of Konya were examined. According to the results, essential oil and crude oil yields were $3.5 \%$ and $5.06 \%$ in dill, $2.25 \%$ and $22.07 \%$ in anise, $2.70 \%$ and $7.34 \%$ in fennel, $1.90 \%$ and $11.26 \%$ in cumin, $0.95 \%$ and $18.48 \%$ in coriander. The main components of dill, fennel, anise, cumin and coriander seed essential oils were carvone (45.221 \%), trans-anethole (86.898 \%), (Z-)-Anethole (92.478\%), cumin aldehyde $(42.900 \%)$ and linalool $(87.238 \%)$ respectively. In crude oils, the main component was determined as C18:1 (oleic acid).

\section{Research Article}

$\begin{array}{ll}\text { Article History } & \\ \text { Received } & : 10.12 .2019 \\ \text { Accepted } & : 07.05 .2020\end{array}$

Keywords

Umbelliferae

Essential Oil

Crude Oil

Chemical composition

Analysis

\title{
Konya Ekolojik Şartlarında Kültüre Alınan Umbelliferae Familyasına ait Bazı Tohumların Uçucu Yağ ve Sabit Yağ Bileşenlerinin Kimyasal Kompozisyonları
}

\section{ÖZET}

Umbelliferae (Apiaceae) yani maydanozgiller, özellikle dünyanın kuzey ılıman bölgelerinde yetişen ve 300 ile 400 civarında cinse sahip geniş bir familyadır. Familyadaki birçok bitki aromatik bitki sinıfına dahildir. Familyadaki özellikle baharat olarak kullanılan türler sirasiyla, rezene (Foeniculum vulgare), anason (Pimpinella anisum), dereotu (Anethum graveolens), kişniş (Coriandrum sativum), ve kimyon (Cuminum cyminum)dur. Bu çalışmada dereotu, rezene, anason, kimyon ve kişniş tohumlarında uçucu yağ ve sabit yağ bileşenleri belirlenmiştir. Konya ekolojik koşullarında yetiştirilen dereotu, rezene, anason, kimyon ve kişniş bitkilerinin meyvelerinde ana etken madde olan uçucu ve sabit yağ oranları ileuçucu ve sabit yağ bileşenlerine bakılmıştır. Elde edilen sonuçlara göre uçucu yağ ve sabit yağ oranları sırasıyla, dereotunda $\% 3.5$ ve $\%$ 5.06 , anasonda $\% 2.25$ ve $\% 22.07$, rezene de $\% 2.70$ ve $\% 7.35$, kimyonda \% 1.90 ve \% 11.26 , kişnişte ise \% 0.95 ve \% 18.48 olarak belirlenmiştir. Dereotu, rezene, anason, kimyon ve kişniş tohum uçucu yağlarının ana bileşenleri sırasıyla karvon (\% 45.221), transanetol (\% 86.898), (Z-) anetol (\% 92.478), kumin aldehit (\% 42.900) ve linalol(\% 87.238)'dür. Sabit yağlarda da ana bileşen C18:1 (oleik asit) olarak belirlenmiştir.

\section{Araştırma Makalesi}

$\begin{array}{ll}\text { Makale Tarihçesi } \\ \text { Geliş Tarihi } & : 10.12 .2019 \\ \text { Kabul Tarihi } & : 07.05 .2020\end{array}$

\section{Anahtar Kelimeler}

Umbelliferae

Uçucu Yağ

Sabit Yağ

Kimyasal Kompozisyon

Analiz

To Cite : Çelik SA, Ayran İ 2020. Chemical Compositions of Essential Oil and Crude Oil of Some Fruits belonging to Umbelliferae Family cultivated in Konya Ecological Conditions KSU J. Agric Nat 23 (4): 1030-1038. DOI: 10.18016/ksutarimdoga.vi.657560. 


\section{INTRODUCTION}

Turkey has a rich biodiversity in terms of medicinal and aromatic species due to its different climatic conditions and favourable geographical structure (Hajyzadeh et al., 2017). Medicinal plants in the world and in our country find an increasing range of use especially in the pharmaceutical and food industries, cosmetics, paints, decorative and feed industry. They are consumed as spice in the food industry at the most. Thyme (Thymus vulgaris), rose (Rosa damascena), poppy (Papaver somniferum), aniseed (Pimpinella anisum), fenugreek (Trigonella foenum-graecum), pepper mint (Mentha piperita), black cumin (Nigella sativa) and similar species have a place in cultured medicinal and aromatic plants. In recent years, the demand has increased rapidly both in the foreign and domestic markets as a result of the use of medicinal and aromatic herbal products.

The main factors determining the importance of medicinal and aromatic plants are the active ingredients. These active ingredients in the plants, especially essential and fixed oils, depend on such many factors as primarily the genetic structure of the plant, climate, environmental factors, cultural treatments, the region of growth of the plant, different parts of the plant (morphogenetic variability) (Singh and Randhawa, 1991), development periods of the plant (ontogenetic variability) (Özel, 2000) and temperature changes during the day (diurnal variability) (Kaçar and Özkan, 2005; Uyanık, 2013). It is important to know the amount and distribution of active ingredient in essential oil plants and the plants belonging to the Umbelliferae family, whose herbs and seed are evaluated separately in particular (Ayhan and Özel, 2017).

Both herbs and frit of the plants of dill, fennel, aniseed, cumin and coriander belonging to the Umbelliferae family are used in salads, soups and sauces as spices and vegetables. In addition, all of these plants are commonly used in medicine, alternative medicine and the public especially in the digestive system, common cold and cough.

Konya is one of the provinces with the least annual precipitation in our country. Due to the very hot and dry summers, irrigation problems are often encountered. This increases secondary metabolite production against stress conditions in medicinal and aromatic plants. For this reason, it was aimed to carry out this study in fruits of dill, fennel, anise, cumin and coriander consumed among the people. In this study, essential oil and crude oil yields and chemical compositions of dill, fennel, anise, cumin and coriander plants grown in Konya ecological conditions were investigated.

\section{MATERIALS AND METHODS}

\section{Plant Materials}

The fruits used in the trial, were dill (Anethum graveolens), fennel (Foeniculum vulgare), anise (Pimpinella anisum), cumin (Cuminum cyminum), coriander (Coriandrum sativum). This study was conducted to essential oil yield, crude oil yield and components of the fruits cultivated, Selçuk University, Faculty of Agriculture, Medical Plants Research and Application Experimental Area in Konya ecological conditions. Field trial was carried out in 2018. All the fruits used were populations. Dill, fennel, anise, cumin and coriander fruis were directly planted in the experimental area by hands in the first week of March (05 March). The growing period of plants were reached 150 days. Trial was set up in three repetitions according to the randomized parcels experimental design. In order to determine the soil properties of the trial area on which the experiment was conducted, the physical and chemical analyzes of the soil sample taken from $0-20 \mathrm{~cm}$ depth were carried out in Selçuk University, Faculty of Agriculture, Department of Soil Laboratory. Soil analysis was given in Table 1.

Table 1. Some Physical and Chemical Properties of Research Trial Soil

Cizelge 1. Deneme Alanı Toprăğna ait Bazı Fiziksel ve Kimyasal Özellikler

\begin{tabular}{|c|c|}
\hline $\begin{array}{l}\text { Properties } \\
\text { (Özellikler) }\end{array}$ & $\begin{array}{l}\text { Amount } \\
\text { (Miktar) }\end{array}$ \\
\hline Sand (\%) & 25.8 \\
\hline Silt (\%) & 38.0 \\
\hline Clay (\%) & 36.2 \\
\hline Texture class & Clayed-loam \\
\hline pH (1:2.5, Soil:Water) & 7.4 \\
\hline EC(Salt) $(1: 5$, Soil:Water $)(\mu \mathrm{S} / \mathrm{cm})$ & 114 \\
\hline $\mathrm{CaCO}_{3}($ Calcitic $)(\%)$ & 53 \\
\hline Orgganic Substance (\%) & 4 \\
\hline İnorganic Nitrogen $\left(\mathrm{NH}_{4}+\mathrm{NO}_{3}-\mathrm{N}\right)(\mathrm{ppm})$ & 30 \\
\hline Phosphorus (P) (ppm) & 40 \\
\hline Potassium (K) (ppm) & 441.5 \\
\hline Calcium $(\mathrm{Ca})(\mathrm{ppm})$ & 5023 \\
\hline Magnesium (Mg) (ppm) & 208.3 \\
\hline Sodium $(\mathrm{Na})(\mathrm{ppm})$ & 48.3 \\
\hline Changeable Na Percentage (\%) & 0.84 \\
\hline Boron (B) (ppm) & 0.3 \\
\hline Copper $(\mathrm{Cu})(\mathrm{ppm})$ & 0.38 \\
\hline Iron $(\mathrm{Fe})(\mathrm{ppm})$ & 0.30 \\
\hline Zinc (Zn) (ppm) & 5.66 \\
\hline Manganese (Mn) (ppm) & 2.70 \\
\hline
\end{tabular}

According to the results, the soil of the experimental area was a loamy structure and high lime rate. The soil was alkaline reaction and salinity problem. The soil was found to be poor in iron, one of the important micronutrients, but rich in organic matter and potassium. Weather proterties of the experimental 
area were given in Table 2. provided from Konya Meteorology Regional Management. The fruits of dill, fennel, anise, cumin, coriander harvested in August, 2018.

Table 2. Average maximum, minimum temperature $\left({ }^{\circ} \mathrm{C}\right)$, humidity $(\%)$ and precipitation $(\mathrm{mm})$ values for long years (1960-2018) and months of research for Konya province.

Cizelge 2. Denemenin yapıldı̆̆g Konya iline ait uzun yıllar için (1960-2018) ortalama, maksimum ve minimum sicaklık $\left({ }^{\circ} \mathrm{C}\right)$,ortalama nispi nem $(\%)$ ve toplam yağiş değeri $(\mathrm{mm})$

\begin{tabular}{|c|c|c|c|c|c|c|c|c|}
\hline \multirow{2}{*}{$\begin{array}{l}\text { Months } \\
\text { (Aylar) }\end{array}$} & \multicolumn{2}{|c|}{$\begin{array}{c}\text { Average Temperature } \\
\text { (Ortalama Sicaklık) } \\
\left({ }^{\circ} \mathrm{C}\right)\end{array}$} & \multirow{2}{*}{$\begin{array}{c}\text { Max. } \\
\text { Temperature } \\
\text { (Mak. } \\
\text { Sicaklik) }\left({ }^{\circ} \mathrm{C}\right) \\
\\
2018\end{array}$} & \multirow{2}{*}{$\begin{array}{c}\text { Min. } \\
\text { Temperature } \\
\text { (Min. Slcaklık) } \\
\left({ }^{\circ} \mathrm{C}\right) \\
\\
\\
\\
\end{array}$} & \multicolumn{2}{|c|}{$\begin{array}{c}\text { Average Relative Humidity (\%) } \\
\text { (Ortalama Nispi Nem) }\end{array}$} & \multicolumn{2}{|c|}{$\begin{array}{c}\text { Total Precipitation }(\mathrm{mm}) \\
\text { (Toplam Yağıs) }\end{array}$} \\
\hline & $\begin{array}{l}\text { Long Years } \\
(1960-2018) \\
(\text { Uzun Ylllar } \\
1960-2018) \\
\end{array}$ & 2018 & & & $\begin{array}{l}\text { Long Years (1960- } \\
\text { 2018) } \\
\text { (Uzun Yillar 1960- } \\
\text { 2018) } \\
\end{array}$ & 2018 & $\begin{array}{l}\text { Long Years } \\
(1960-2018) \\
(\text { Uzun Yillar } \\
1960-2018)\end{array}$ & 2018 \\
\hline January & -0.3 & 1.3 & 13.3 & -10.2 & 76.7 & 82.3 & 36.6 & 55.8 \\
\hline February & 1.2 & 5.8 & 18.0 & -6.8 & 72.2 & 72.2 & 28.5 & 11.4 \\
\hline March & 5.6 & 10.0 & 25.1 & -2.7 & 64 & 58.4 & 27.6 & 28.1 \\
\hline April & 10.9 & 14.0 & 26.8 & 0.4 & 58.3 & 47.0 & 33.5 & 7.2 \\
\hline May & 15.7 & 17.3 & 28.1 & 5.9 & 55.9 & 58.4 & 44 & 52.0 \\
\hline June & 20.1 & 21.2 & 33.7 & 10.5 & 48.4 & 50.3 & 24 & 97.9 \\
\hline July & 23.4 & 25.1 & 34.5 & 13.7 & 42.1 & 39.9 & 6.6 & 8.2 \\
\hline August & 22.8 & 24.6 & 34.4 & 13.8 & 42.9 & 35.9 & 5.5 & 0.2 \\
\hline September & 18.4 & 20.1 & 33.6 & 9.0 & 48 & 42.3 & 12.8 & 5.9 \\
\hline October & 12.4 & 13.9 & 25.5 & -2.2 & 60.4 & 60.7 & 32 & 51.8 \\
\hline November & 6 & 7.9 & 20.5 & -4.2 & 70.4 & 67.8 & 32.6 & 20.6 \\
\hline December & 1.6 & 2.9 & 13.3 & 14.4 & 77.3 & 82.0 & 43.3 & 81.8 \\
\hline Average & 11.48 & 13.67 & 25.6 & 1.06 & 62.5 & 58.1 & - & - \\
\hline Total & - & - & - & - & - & - & 327 & 420.9 \\
\hline
\end{tabular}

\section{Essential Oil Distillation and Analysis}

The fruits were milled with a grinder (Foss Kniftec 1095, Denmark) to analyse essential oil distillation. Then whole ground fruits $(100 \mathrm{~g})$ subjected to hydrodistillation for $3 \mathrm{~h}$ using Clevenger type apparatus to produce essential oil. Essential oil is calculated as volume ( $\mathrm{ml} / 100 \mathrm{~g})$. GC-MS instrument was used to determine the essential oil components. The essential oils were stored at $-20^{\circ} \mathrm{C}$ until analyzed. GC-MS analysis was performed on a Agilent $6890 \mathrm{~N}$ Network GC system combined with Agilent 5975 C VL MSD Network Mass Selective Detector. The GC conditions were; column, DB Waxe tr; $60.0 \mathrm{~m} \mathrm{x}$ $0.25 \mathrm{~mm} \times 0.25 \mu \mathrm{m}$; oven temperature programme: The column held initially at $60{ }^{\circ} \mathrm{C}$ for $10 \mathrm{~min}$ after injection, then increased to $220{ }^{\circ} \mathrm{C}$ with $4{ }^{\circ} \mathrm{C} \mathrm{min}^{-1}$ heating ramp for $10 \mathrm{~min}$ and increased to $240{ }^{\circ} \mathrm{C}$ with $10{ }^{\circ} \mathrm{C} \mathrm{min}^{-1}$ heating ramp without hold; inject or temperature $250{ }^{\circ} \mathrm{C}$; carrier gas; $\mathrm{He}$; inlet pressure, $9.60 \mathrm{psi}$; linear gas velocity, $7 \mathrm{~cm} \mathrm{sec}^{-1}$; initial flow 0.3

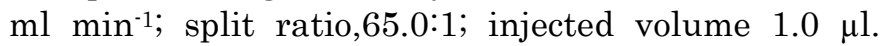
Computer matching against commercial libraries (Wiley GC-MS Library, Adams Library, MassFinder 3 Library) as well as MS literature data was used for the identification of essential oil components(European Pharmacopoeia 7.0).

\section{Isolation and Derivatization of The Fruit Crude Oils}

The fruits of dill, fennel, anise, cumin and coriander were independently subjected to continuous extraction technique with diethyl ether for $8 \mathrm{~h}$ using
Soxhlet apparatus. The organic phases were evaporated in vacuo until dryness to give the crude oils. Prior to GC-MS analysis, trans-methyl derivatives of the crude oils were prepared. Fatty acid profiles were determined as fatty acid methyl esters (FAMEs) and the FAMEs were dissolved in $n$-hexane for injection and analyzed by GC-MS (European Pharmacopoeia 7.0).

\section{Fruit Crude Oil Analysis by GC-MS}

GC-MS analysis was performed on a Agilent $6890 \mathrm{~N}$ Network GC system combined with Agilent 5975 C VL MSD Network Mass Selective Detector. Determination of the components in the fruit fatty oils of dill, fennel, anise, cumin and coriander were performed by comparison of their mass spectra with Wiley, Famed-23 and Nist GC-MS Libraries and retention indices $(\mathrm{RI})$, relative to $\mathrm{n}$-alkanes as well as corresponding data from relevant literature. The percentages of the components were calculated from the GC peak areas using the normalization method.

\section{CONCLUSION and DISCUSSION}

\section{Yields of Essential Oil and Crude Oil of the Fruits (\%)}

Essential oil yields (\%) of dill, fennel, aniseed, cumin and coriander fruits were determined in the clevenger apparatus and crude oil yields (\%) were determined in the soxhlet apparatus. Accordingly, the essential oil and crude oil yields of the fruits were given in Table 3. 
Table 3. Essential oil (\%) and crude oil (\%) yields of some plant fruits belonging to Umbelliferae family

Cizelge 3. Umbelliferae familyasına ait bazı bitkilerin meyvelerine ait uçucu yă̆ ve sabit yă̆ miktarları (\%)

\begin{tabular}{l|cc}
\hline $\begin{array}{l}\text { TheFruits } \\
\text { (Meyveler) }\end{array}$ & $\begin{array}{c}\text { Essential Oil Yield (\%) } \\
\text { (Uçucu Yăg Miktarı) }\end{array}$ & $\begin{array}{c}\text { Crude Oil Yield (\%) } \\
\text { (Sabit Yă̆ Miktarı) }\end{array}$ \\
\hline Dill & 3.15 & 5.06 \\
Fennel & 2.70 & 7.34 \\
Anise & 2.25 & 22.07 \\
Cumin & 1.90 & 11.26 \\
Coriander & 0.95 & 18.48 \\
\hline
\end{tabular}

The essential oil yields of dill, fennel, aniseed, cumin and coriander fruits were determined as $3.15 \%$, $2.70 \%, 2.25 \%, 1.90 \%$ and $0.95 \%$ respectively. Şanlı et al. (2012), essential oil yields in the fruits of dill, fennel, aniseed, cumin and coriander grown in the ecological conditions of Burdur were respectively determined as $3.02 \%, 2.74 \%, 2.68 \%, 1.82 \%$ and $0.32 \%$. In another study reported that average essential oil rates were determined as $3.18 \%$ in dill fruit, $2.49 \%$ in fennel fruit, $3.33 \%$ in aniseed fruit, $1.77 \%$ in cumin fruit and $0.42 \%$ in coriander fruit in Isparta ecological conditions (Keskin and Baydar, 2016). According to the studies investigated with dill fruits, Charles et al. (1995) determined essential oil yield of the fruit as 1.75\%- 4\%, Tian et al. (2011) determined essential oil yield of dill fruit grown in China as 3.5\% and Akgül (1986) determined as 2.2\%- $3 \%$. When the studies conducted with fennel fruit are examined, Uzun et al. (2011) determined essential oil yield of the fruit as 2.67\%- $3.09 \%$, Özkan and Gürbüz (2000) determined essential oil yield of the fennel fruit grown in the conditions of Ankara as 1.93\%-2.28\% and Sanlı et al. (2012) determined as $2.74 \%$. When the studies conducted with aniseed fruit are examined, Keskin and Baydar (2016) determined essential oil yield of the fruit as $3.10 \%^{-} 3.60 \%$, Haşimi et al. (2014) determined essential oil yield of aniseed fruit as $1.94 \%$, Zheljazkov et al. (2013b) determined as $0.09 \%$ $2.01 \%$ and Şanl et al. (2012) determined as $2.68 \%$. When the studies conducted with cumin fruit are examined, Haşimi et al. (2014) determined essential oil yield of cumin fruit as $1.94 \%$, Keskin and Baydar (2016) determined as $1.47 \%-2.13 \%$ and Şanll et al. (2012) determined as $1.82 \%$. When the studies conducted with coriander fruit are examined, Niamah et al. (2016) determined essential oil yield of coriander fruit as 2\%, Keskin and Baydar (2016) determined as $0.40 \%-0.47 \%$ and Şanl et al. (2012) determined as $0.32 \%$.

Crude oil yields determined in the fruits were given in Table 3. The crudel oil yields of dill, fennel, aniseed, cumin and coriander fruits were respectively determined as $5.06 \%, 7.3422 .07 \%, 11.26 \%$ and $18.48 \%$. The crude oil yields of coriander genotypes were determined as 18.64\%-22.53\% (Gökduman and Telci, 2018). In another research, it was reported that coriander's crude oil was $13 \%-21 \%$, cumin's crude oil was $10 \%^{-} 15 \%$ and aniseed's crude oil was $30 \%$ (Gruenwald et al., 2004). The results were consistent with other results.

The results of the study revealed that the essential oil and crude oil ratios were in parallel with the other studies.

\section{Essential Oil Compositions of the Fruits}

The essential oil components of the dill fruit were given in Table 4. The essential oil components of dill, fennel, aniseed, cumin and coriander determined in the GC-MS. Wiley, Nist-Spectral and Volatile libraries were used to determine components in the GC-MS.

Table 4. Chemical composition of Anethum graveolens essential oil(\%)

Cizelge 4. Anethum graveolens meyvesinin uçucu yağ kimyasal kompozisyonu (\%)

\begin{tabular}{|c|c|c|c|c|c|c|c|}
\hline $\begin{array}{l}\text { No } \\
\text { (Sira } \\
\text { No) }\end{array}$ & $\begin{array}{c}\mathrm{RI} \\
\text { (Retensiyon } \\
\text { Indisi) }\end{array}$ & $\begin{array}{c}\text { Compound } \\
\text { (Bilessen) }\end{array}$ & $\begin{array}{c}\text { Amount } \\
\text { (\%) } \\
\text { (Miktar) }\end{array}$ & $\begin{array}{c}\text { No } \\
\text { (Sira No) }\end{array}$ & $\begin{array}{c}\mathrm{RI} \\
\text { (Retensiyon } \\
\text { Indisi) }\end{array}$ & $\begin{array}{c}\text { Compound } \\
\text { (Bileşen) }\end{array}$ & $\begin{array}{c}\text { Amount } \\
\text { (\%) } \\
\text { (Miktar) }\end{array}$ \\
\hline 1 & 1025 & a-pinene & 0.045 & 15 & 1647 & trans-dihydrocarvone & 9.373 \\
\hline 2 & 1134 & Sabinene & 0.022 & 16 & 1673 & Estragole & 0.171 \\
\hline 3 & 1186 & a-phellandrene & 0.342 & 17 & 1758 & Carvone & 45.221 \\
\hline 4 & 1246 & Limonene & 35.905 & 18 & 1820 & Anethole & 3.716 \\
\hline 5 & 1248 & 8-phellandrene & 0.053 & 19 & 1826 & $\begin{array}{c}\text { 6-oxo-2,3,5,6-tetrahydro- } \\
\text { 1-H-pyrazine }\end{array}$ & 0.030 \\
\hline 6 & 1253 & (1,3,8-para-menthatriene) & 0.254 & 20 & 1832 & Isophorone & 0.042 \\
\hline 7 & 1260 & Ortho-cymene & 0.103 & 21 & 2045 & Para anisaldehyde & 0.019 \\
\hline 8 & 1409 & Trans-epoxy־cymene & 0.042 & 22 & 2210 & Carvacrol & 0.008 \\
\hline 9 & 1441 & Para-cymene & 0.138 & 23 & 2224 & Elemicin & 0.011 \\
\hline 10 & 1451 & cis-limonene oxide & 0.097 & 24 & 2272 & Myristicin & 0.927 \\
\hline 11 & 1464 & Trans-limonene oxide & 0.067 & 25 & 2371 & Dillapiole & 1.681 \\
\hline 12 & 1524 & Dill ether & 0.107 & \multicolumn{3}{|c|}{ TOTAL } & 100 \\
\hline 13 & 1587 & Artemisiaketone & 0.026 & & & & \\
\hline 14 & 1624 & Cis-dihydrocarvone & 1.598 & & & & \\
\hline
\end{tabular}


When the essential oil components of the dill fruit were examined, primary components were carvone (45.221\%), limonene (35.909\%), transdihydrocarvone $(9.373 \%)$, anethole (3.716 \%), dillapiole $(1.681 \%)$ and dillether $(0.107 \%)$. The number of totally determined components was 25 and the total amount was $100 \%$. Aside from these components, para-anisaldehyde $(0.019 \%)$, cisdihydrocarvone (1.598\%), a-phellandrene (0.342\%) were determined. Main components (carvone, limonene, trans-dihydrocarvone, anethole, dillapiole and dillether) constitute $96.007 \%$ of the amount of all the components. Carvone was found to be the main component of the fruit essential oil when the studies conducted with dill were examined. Şanlı et al. (2012) found the essential component of the fruit essential oil as D-Carvone (71.80\%) and $\alpha$-fenchene (11.85\%) and limonene $(9.75 \%)$ were other components. In other studies, the rate of carvone was determined as 18.18-81.15\% (Charles et al., 1995), 81.35-89.98\%
(Hah and Ea, 2016), 75.2\% (Radulescu et al., 2010), 85.9\% (Stanojevic et al., 2016), 37.87-67.76\% (Keskin and Baydar, 2016). Orhan et al. (2013) found that the main component of the dill herb's essential oil is $\alpha^{-}$ phellandrene (47.748\% in organic dill and $27.940 \%$ in culture dill). In our study, the main component was determined as carvone. It was in parallel with other studies. However, the reason for the fact that its quantity was slightly lower than others could be explained as climate, environmental conditions and applied agricultural techniques. It was thought to be effective that it the ecological conditions of Konya was more arid.

The essential oil components of the fennel fruit were given in Table 5. When the essential oil components of the fennel fruit were examined, main components were Trans-anethole (86.898 \%), Limonene $(5.210 \%)$, p-ally-anisole (3.992\%), L-fenchone $(1.427 \%)$, pAnisealdehyde $(0.457 \%)$ and B-ocimene $(0.713 \%)$.

Table 5. Chemical composition of Foeniculum vulgare fruit essential oil (\%)

Çizelge 5. Foeniculum vulgare meyvesinin uçucu yağ kimyasal kompozisyonu (\%)

\begin{tabular}{|c|c|c|c|c|c|c|c|}
\hline $\begin{array}{l}\text { No } \\
\text { (Sira } \\
\text { No) }\end{array}$ & $\begin{array}{c}\mathrm{RI} \\
\text { (Retensiyon } \\
\text { Indisi) }\end{array}$ & $\begin{array}{c}\text { Compound } \\
\text { (Bileşen) }\end{array}$ & $\begin{array}{c}\text { Amoun(\%) } \\
\text { (Miktar) }\end{array}$ & $\begin{array}{l}\text { No } \\
\text { (Sira } \\
\text { No) } \\
\end{array}$ & $\begin{array}{c}\mathrm{RI} \\
\text { (Retensiyon } \\
\text { Indisi) }\end{array}$ & Compound (Bileşen) & $\begin{array}{c}\text { Amount (\%) } \\
\text { (Miktar) }\end{array}$ \\
\hline 1 & 1025 & $\alpha^{-}$-pinene & 0.250 & 12 & 1653 & p-ally-anisole & 3.992 \\
\hline 2 & 1117 & 8-pinene & 0.030 & 13 & 1706 & Germacrene D & 0.050 \\
\hline 3 & 1132 & Sabinene & 0.188 & 14 & 1881 & Trans-anethole & 86.898 \\
\hline 4 & 1180 & B-myrcene & 0.281 & 15 & 2047 & p-Anisaldehyde & 0.457 \\
\hline 5 & 1230 & Limonene & 5.210 & 16 & 2168 & Anisylacetone & 0.017 \\
\hline 6 & 1263 & B-ocimene & 0.713 & 17 & 2184 & Methylısoeugenol & 0.012 \\
\hline 7 & 1277 & $\mathrm{Y}^{\text {-terpinene }}$ & 0.088 & 18 & 2211 & Carvacrol & 0.006 \\
\hline 8 & 1302 & p-cymene & 0.031 & 19 & 2222 & 1-M-Anisyl-1-propanone & 0.015 \\
\hline 9 & 1317 & $\alpha$-terpinolene & 0.028 & 20 & 2269 & $\begin{array}{l}\text { 1-Allyl-3-Methoxy-4,5- } \\
\text { MethylEnedioxybenzene }\end{array}$ & 0.008 \\
\hline 10 & 1429 & L-fenchone & 1.427 & 21 & 2365 & Dillapiole & 0.017 \\
\hline 11 & 1535 & Camphor & 0.040 & \multicolumn{3}{|c|}{ TOTAL } & 99.758 \\
\hline
\end{tabular}

The number of the totally determined components was 21 and the total amount was $99.758 \%$. In addition to these components, the components of $a^{-}$ pinene $(0.250 \%)$, sabinene $(0.188 \%)$, B-myrcene $(0.281 \%)$ were determined. Main components (Transanethole, limonene, $\mathrm{p}$-ally-anisole, L-fenchone, $\mathrm{p}^{-}$ Anisealdehyde and8-ocimene) constituted $96.697 \%$ of the amount of all the components. It was also seen in the studies that the major component of the essential oil of fennel fruit was trans anethole. The amounts of trans anethole detected in these studies were $85.22 \%$ (Şanlı et al., 2012), 47\%- 80.2\% (Bowes and Zheljaskov, 2005), 32.6\%-59.4\% (Zheljaskov et al., 2013), 60.15\%- 84.20\% (Rebey et al., 2016), 53.51\% (Negahban et al., 2015), 34.8\%- 82\% (Raal et al., 2012) and 79.67\%-89.13\% (Keskin and Baydar, 2016). In addition, the other major component identified in the other studies was fenchone (Shahat et al., 2011). The amounts of fenchone in the literature were $6.22 \%$
(Şanlı et al., 2012), 0\%- 8.2\%(Bowes and Zheljaskov, 2005), 9.8-22.7\% (Zheljaskov et al., 2013), 4.26\%$11.12 \%$ (Rebey et al.,2016), 8.32\% (Negahban et al., 2015), 1.6\% - 22.8\% (Raal et al., 2012). In some studies the major component of fennel essential oil was trans-anethole, while in others it had been identified as fenchone. This was because transanethole and fenchone were two main components in the fennel essential oil. The reason for the difference in these components was kemataxonomic and chemotypic as well as regional, ie ecological differences. The amount of trans anethole obtained in our study was compatible with the result in other studies.

The essential oil components of the aniseed fruit were given in Table 6. The number of the totally determined components was 16 and the total amount was $99.866 \%$. The main essential oil components of anise fruit were (Z-)-anethole (92.478\%), Estragole 
Table 6. Chemical composition of Pimpinella anisum fruit essential oil

Cizelge 6. Pimpinella anisum meyvesinin uçucu yağ kimyasal kompozisyonu (\%)

\begin{tabular}{|c|c|c|c|c|c|c|c|}
\hline $\begin{array}{l}\text { No } \\
\text { (Sira } \\
\text { No) }\end{array}$ & $\begin{array}{c}\mathrm{RI} \\
\text { (Retensiyon } \\
\text { Indisi) }\end{array}$ & $\begin{array}{c}\text { Compound } \\
\text { (Bileşen) }\end{array}$ & $\underset{\text { (Miktar) }}{\text { Amount (\%) }}$ & $\begin{array}{l}\text { No } \\
\text { (Sira No) }\end{array}$ & $\begin{array}{c}\mathrm{RI} \\
\text { (Retensiyon } \\
\text { Indisi) }\end{array}$ & $\begin{array}{c}\text { Compound } \\
\text { (Bilessen) }\end{array}$ & $\begin{array}{c}\text { Amount } \\
\text { (\%) } \\
\text { (Miktar) }\end{array}$ \\
\hline 1 & 1201 & Limonene & 0.347 & 10 & 2019 & Para-anisaldehyde & 0.820 \\
\hline 2 & 1299 & Fenchone & 0.110 & 11 & 2119 & $\begin{array}{c}\text { 1-(4-methoxy phenyl)-2- } \\
\text { propanone }\end{array}$ & 0.031 \\
\hline 3 & 1683 & Estragole & 3.360 & 12 & 2216 & Carvacrol & 0.030 \\
\hline 4 & 1700 & a-himachalene & 0.070 & 13 & 2228 & $\begin{array}{c}\text { 1-(4-methoxy phenyl)-1- } \\
\text { propanone }\end{array}$ & 0.028 \\
\hline 5 & 1749 & $\mathrm{Y}$-himachalene & 1.214 & 14 & 2381 & Dil apiole & 0.014 \\
\hline 6 & 1760 & $\alpha$-zingiberene & 0.170 & 15 & 2646 & 3,4-Dimethoxystyrene & 0.626 \\
\hline 7 & 1767 & (E-) Anethole & 0.396 & 16 & 2897 & 3-hydroxycarbofuran & 0.093 \\
\hline 8 & 1811 & Curcumene & 0.079 & \multirow{2}{*}{\multicolumn{3}{|c|}{ TOTAL }} & \\
\hline 9 & 1865 & (Z-) Anethole & 92.478 & & & & 99.866 \\
\hline
\end{tabular}

(3.360\%), himachalene (1.214\%), L-fenchone (1.427\%), para-Anisealdehyde (0.820\%) and ( E-) Anethole (0.396\%). In addition to these components, limonene $(0.347 \%)$, fenchone $(0.110 \%), a^{-}$ zingiberene $(0.170 \%)$ were determined. Main components (Z-)-anethole, estragole, $\mathrm{Y}^{\text {-himachalene, }}$ L-fenchone, para-Anisealdehyde and (E-) Anethole) constituted $99.695 \%$ of the amount of all the components. Şanlı et al. (2012) found that the main component of the essential oil of aniseed was trans anethole (85.27\%). The main component was determined as trans anethole (avg. 95.69\%) in 2016 (Keskin and Baydar, 2016). In other studies, the amounts of trans anethole were investigated to be $52.94 \%$ (Haşimi et al., 2014), 93.9\% (Shojaii and Fard, 2012), 93.6\%-96.2\% (Zheljazkov et al., 2013b), 92.4\% (Saibi et al., 2013) and 90.35\% (Omidbaigi et al., 2003). The amount of trans anethole detected in our study was $92.478 \%$. In our study, trans anethole was determined as the main component and the results were consistent with other studies.

The essential oil components of the cumin fruit were given in Table 7 . The main components of cumin fruit essential oil were identified as Cuminaldehyde (42.900\%), orth-terpinen-7-al (22.649\%), a-terpinen-7al $(9.661 \%)$, ortho-cymene $(8.283 \%), \mathrm{Y}^{\text {-terpinene }}$ $(5.305 \%$ and 8 -pinene $(3.430 \%)$. In total, 37 compounds were identified $99.903 \%$ of the total essential oil constituents. Limonene $(0.268 \%)$, trans1-decalone (1.334\%), 4-methyl-1-cyclohexane ( 0.438 $\%$ were found as other constituents in the oil. Main

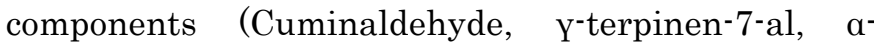
terpinen-7-al, ortho-cymene, $\mathrm{Y}^{- \text {terpinene }}$ and $\mathrm{B}^{-}$ pinene) constitute $92.228 \%$ of the amount of all the

Table 7. Chemical composition of Cuminum cyminum fruit essential oil (\%)

Çizelge 7. Cuminum cyminum meyvesinin uçucu yağ kimyasal kompozisyonu (\%)

\begin{tabular}{|c|c|c|c|c|c|c|c|}
\hline $\begin{array}{l}\text { No } \\
\text { (Sira } \\
\text { No) }\end{array}$ & $\begin{array}{c}\mathrm{RI} \\
\text { (Retensiyon } \\
\text { Indisi) }\end{array}$ & $\begin{array}{l}\text { Compound } \\
\text { (Bileşen) }\end{array}$ & $\begin{array}{c}\text { Amount } \\
(\%) \\
\text { (Miktar) }\end{array}$ & $\begin{array}{l}\text { No } \\
\text { (Sira } \\
\text { No) }\end{array}$ & $\begin{array}{c}\mathrm{RI} \\
\text { (Retensiyon } \\
\text { Indisi) }\end{array}$ & $\begin{array}{l}\text { Compound } \\
\text { (Bileşen) }\end{array}$ & $\begin{array}{c}\text { Amount (\%) } \\
\text { (Miktar) }\end{array}$ \\
\hline 1 & 1066 & B-pinene & 3.430 & 20 & 1557 & B-bisabolene & 0.073 \\
\hline 2 & 1078 & Sabinene & 0.149 & 21 & 1577 & $\begin{array}{l}2 \text {-(2-hydroxy cyclohexyl)- } \\
\text { furan }\end{array}$ & 0.320 \\
\hline 3 & 1097 & Myrcene & 0.279 & 22 & 1644 & (Z) Anethole & 0.351 \\
\hline 4 & 1109 & a-phellandrene & 0.143 & 23 & 1656 & Cuminaldehyde (Cuminal) & 42.900 \\
\hline 5 & 1128 & Limonene & 0.268 & 24 & 1667 & Y-Terpinen-7-al & 22.649 \\
\hline 6 & 1153 & 8-phellandrene & 0.125 & 25 & 1713 & $\alpha$-Terpinen-7-al & 9.661 \\
\hline 7 & 1168 & $\mathrm{Y}$-terpinene & 5.305 & 26 & 1716 & 2,4(10)-thujadien & 0.064 \\
\hline 8 & 1204 & Orthocymene & 8.283 & 27 & 1719 & 4'-methoxy-4-flavanol & 0.054 \\
\hline 9 & 1283 & Cis-sabinenehydrate & 0.035 & 28 & 1741 & 4-1sopropylphenylacetic acid & 0.154 \\
\hline 10 & 1297 & $\alpha$-terpinolene & 0.103 & 29 & 1784 & 1,4-p-Menthadien-7-ol & 0.167 \\
\hline 11 & 1433 & Cis-para-Menth-2-en-1-ol & 0.144 & 30 & 1831 & Cuminalcohol (cymen-7-ol) & 0.609 \\
\hline 12 & 1451 & 4-t-pentylcyclohexene & 0.132 & 31 & 1848 & Caratol & 0.869 \\
\hline 13 & 1473 & Terpinen-4-ol & 0.249 & 32 & 1872 & Veridiflorol & 0.184 \\
\hline 14 & 1497 & Trans-1-decalone & 1.334 & 33 & 1908 & Caryophyllene oxide & 0.215 \\
\hline 15 & 1512 & 4-methyl-1-cyclohexane & 0.438 & 34 & 1932 & 2-Acetylcyclo pentanone & 0.229 \\
\hline 16 & 1514 & B-farnesene & 0.073 & 35 & 1979 & 4-hydrazinobenzonitrile & 0.053 \\
\hline 17 & 1534 & $\begin{array}{l}\text { a-terpineol (p-menth-1-en- } \\
\text { 8-ol) }\end{array}$ & 0.089 & 36 & 2008 & 1-Bromo-5-hexanone & 0.086 \\
\hline 18 & 1546 & B-acoradiene & 0.187 & 37 & 2103 & 4-hydroxy-cryptone & 0.437 \\
\hline 19 & 1553 & Trans-piperitol & 0.062 & & & TOTAL & 99.903 \\
\hline
\end{tabular}


components. The essential oil of the cumin fruit was determined as $2.5 \%$ - $4 \%$, its main component was determined as cuminaldehyde and it was reported that limonene, eugenol, a-pinene an 6-pinene were determined (Gohari and Saeidna, 2011). When essential oil components are examined in the study in the conditions of Burdur, 2-caren-10-al (\% 50.02) was determined as the main component and cuminal was determined as $22.25 \%$ (Şanl et al., 2012). In another study conducted in India in 2018, the main component was determined as cuminaldehyde at the rate of $74.62 \%$ and 8 -pinene, $p$-cymene, $\alpha$-terpinen-7al were also determined (Gotmare and Tambe, 2018). Rana (2014) described cuminaldehyde (49.4\%) as the main component in the essential oil of the cumin fruit and determined $\mathrm{p}$-cymene (17.4\%), B-pinene (6.3\%), $\alpha^{-}$ terpinen-7-al (6.8\%), $\mathrm{Y}^{\text {-terpinene }}(6.1 \%)$. According to another study conducted in Isparta, a-thujenal (average 35.69\%) was determined as the main component (Keskin and Baydar, 2016). Kan et al. (2007) examined the effect of harvest time on essential oil and found cuminaldehyde (19.9\%-20.4\%) the main component. Studies suggested that the results we have obtained was consistent with the literatures.

Components of coriander fruit essential oil are given in Table 8. Linalool (87.238 \%), Geraniol (4.076\%), geranyl acetate $(3.542 \%)$, camphor $(2.160 \%)$, (2E) Dodecenal (1.347 \%) were identified as main constituents in the essential oil. In total, 28 compounds were identified $99.994 \%$ of the total essential oil constituents. Limonene (0.027\%), (2E) Decanal $(0.120 \%)$, a-terpineol $(0.240 \%)$ and cislinalool oxide $(0.092 \%)$ were determined as other essential oil components of coriander. Main components (Linalool, geraniol, geranyl acetate, camphor, (2E) Dodecenal) were constituted 98.363\% of the amount of all the components. The main component of the essential oil of the coriander fruit is linalool as stated in the studies. According to other studies, the amounts of linalool were $37.7 \%$ (Bhuiyan et al., 2009), 95.56\% (Şanlı et al., 2012), 59.14\% (Niamah and Alali, 2016), 69.60\% (Anwar et al., 2011), 58.0-80.3\% (Orav et al., 2010), 81.85\%- 88.94\% (Keskin and Baydar, 2016).

\section{Crude Oil Components of the Fruits}

Fatty acid methyl esters of the fruit of dill, fennel, aniseed, cumin and coriander were determined in the GC-MS. Wiley, Nist-Spectral and Famed 23 libraries were used to determine the components in the GCMS. Fatty acid components of dill, fennel, aniseed, cumin and coriander were given in Table 9 .

The main fatty acid component of dill, fennel, aniseed, cumin and coriander was oleic acid (6Z-octadecanoic acid- petroselinic acid- C18:1). The highest amount of oleic acid was determined in the dill fruit (\%88.296), while the lowest amount of oleic acid was determined in the cumin fruit (66.593\%). The amount of oleic acid in fennel, coriander and aniseed was $84.356 \%$, $79.651 \%$ and $70.818 \%$ respectively. The other major fatty acid component was identified as linoleic acid (C18:2). The highest amount of linoleic acid was $26.464 \%$ in the cumin fruit and the lowest was $6.625 \%$ in the dill fruit. As seen, the amounts of oleic acid and linoleic acid were inversely proportional. Other determined unsaturated fatty acids are palmitoleic acid (C16:1), linolenic acid (C18:3) and gadoleic (9-eicosenic acid- C20:1) acid. Palmitic acid (C16:0) and arachidic acid (C20:0) were determined as saturated fatty acids. The highest amount of palmitic acid was determined in coriander $(5.057 \%)$ and the lowest amount was determined in cumin (4.338\%). Arachidic acid was found only in coriander (0.954\%) and cumin $(2.017 \%)$.

Table 8. Chemical composition of Coriandrum sativum fruit essential oil

Cizelge 8. Coriandrum sativum meyvesinin uçucu yă̆ kimyasal kompozisyonu (\%)

\begin{tabular}{|c|c|l|c|}
\hline $\begin{array}{c}\text { No } \\
\text { (Sira } \\
\text { No) }\end{array}$ & $\begin{array}{c}\text { RI } \\
\text { (Retensiyon } \\
\text { Indisi) }\end{array}$ & Compound (Bilessen) & $\begin{array}{c}\text { Amount } \\
(\%) \\
\text { (Miktar) }\end{array}$ \\
\hline 1 & 1197 & Limonene & 0.027 \\
\hline 2 & 1240 & Y-terpinene & 0.180 \\
\hline 3 & 1263 & Ortho-cymene & 0.035 \\
\hline 4 & 1439 & Cis-linalool oxide & 0.092 \\
\hline 5 & 1460 & Cis-sabinenehydrate & 0.050 \\
\hline 6 & 1467 & Trans-linalool oxide & 0.074 \\
\hline 7 & 1498 & Decanal & 0.094 \\
\hline 8 & 1521 & Camphor & 2.160 \\
\hline 9 & 1543 & Linalool & 87.238 \\
\hline 10 & 1594 & Terpinen-4-ol & 0.047 \\
\hline 11 & 1606 & Caryophyllene & 0.043 \\
\hline 12 & 1649 & (2E-) Decanal & 0.120 \\
\hline 13 & 1689 & B-citral & 0.029 \\
\hline 14 & 1695 & Myrtenylacetate & 0.042 \\
\hline 15 & 1701 & a-terpineol & 0.240 \\
\hline 16 & 1726 & Nerylpropanoate & 0.037 \\
\hline 17 & 1738 & Geranial & 0.062 \\
\hline 18 & 1747 & Bicyclogermacrene & 0.058 \\
\hline 19 & 1757 & Geranylacetate & 3.542 \\
\hline 20 & 1768 & Decylalcohol & 0.043 \\
\hline 21 & 1773 & B-citronellol & 0.053 \\
\hline 22 & 1805 & 1,3,6-octatriene & 0.070 \\
\hline 23 & 1817 & (2E-) dodecen-1-ol & 0.060 \\
\hline 24 & 1849 & Geraniol & 4.076 \\
\hline 25 & 1860 & (2E) Dodecenal & 1.347 \\
\hline 26 & 2003 & E-2-tetradecen-1-ol & 0.072 \\
\hline 27 & 2009 & Nerolidol & 0.034 \\
\hline 28 & 2049 & (2E-) tridecen-1-al & 0.069 \\
\hline & & TOTAL & $\mathbf{9 9 . 9 9 4}$ \\
\hline & & & \\
\hline
\end{tabular}


Table 9. Fatty Acid Components of Dill, Fennel, Anise, Cumin, Coriander, Fruit Crude Oil (\%) Çizelge 9. Dereotu, Rezene, Anason, Kimyon ve Kişniş meyvelerine ait Yağ Asidi Bileşenleri (\%)

\begin{tabular}{|l|c|c|c|c|c|c|c|}
\hline $\begin{array}{l}\text { Fatty Acids } \\
\text { (Yağ Asitleri) }\end{array}$ & $\begin{array}{c}\text { R.T. } \\
\text { (Retensiyon } \\
\text { Zamant) }\end{array}$ & $\begin{array}{c}\text { R.I. } \\
\text { Retensiyon } \\
\text { Indisi) }\end{array}$ & $\begin{array}{c}\text { Anethum } \\
\text { graveolens }\end{array}$ & $\begin{array}{c}\text { Foeniculum } \\
\text { vulgare }\end{array}$ & $\begin{array}{c}\text { Pimpinella } \\
\text { anisum }\end{array}$ & $\begin{array}{c}\text { Cuminum } \\
\text { cyminum }\end{array}$ & $\begin{array}{c}\text { Coriandrum } \\
\text { sativum }\end{array}$ \\
\hline C16:0 (Palmitic Acid) & 25.473 & 1285 & 4.392 & 5.048 & 4.980 & 4.338 & 5.057 \\
\hline C16:1(Palmitoleic Acid) & 26.401 & 1296 & 0.435 & 0.283 & 0.503 & 0.371 & 0.472 \\
\hline C18:1 (Oleic Acid) & 33.07 & 1591 & 88.296 & 84.356 & 70.818 & 66.593 & 79.651 \\
\hline C18:2 (Linoleic Acid) & 34.788 & 1649 & 6.625 & 10.014 & 23.343 & 26.464 & 12.587 \\
\hline C18:3 (Linolenic Acid) & 37.426 & 1742 & 0.252 & 0.299 & 0.356 & 0.216 & 0.262 \\
\hline C20:0(Eicosenoic Acid) & 40.257 & 1846 & - & - & - & 2.017 & 0.954 \\
\hline C20:1 (Arashidic Acid) & 41.372 & 1887 & - & - & - & - & 1.017 \\
\hline
\end{tabular}

The crude oils of some species belonging to the Umbelliferae family such as parsley, fennel, dill, aniseed, cumin, coriander, are very rich $(55-90 \%)$ in petroselinic acid (C18:1, cis 6), which is not found in the oil of other plants, and can be used both as food and industrial oil. In a study conducted in the conditions of Isparta, the main fatty acid component of aniseed, dill, fennel, cumin and coriander was determined as petroselinic acid (55.44\%-87.28\%) (Keskin and Baydar, 2016). In our study, the main fatty acid component was also determined as petroselinic acid.

\section{REFERENCES}

Akgül A 1986. Dereotu, Havuç, Kereviz ve Maydanoz

Tohum Uçucu Yağlarının Analitik Kriterleri Üzerine Araştırma, Atatürk Üniversitesi Ziraat Fakültesi Dergisi 17(1-4): 25-30.

Anwar F, Sulman M, Hussain AI, Saari N, Iqbal S, Rashid U 2011. Physicochemical composition of hydro-distilled essential oil from coriander (Coriandrum sativum L.) seeds cultivated in Pakistan, Journal of Medicinal Plants Research 5(15): 3537-3544.

AOAC Official Method 994.12, Amino Acids in Feeds. Official Methods of Analysis of AOAC Int. 18th Ed, 2005, Rev. 4. 2011, Chapter 4, pp 9-19.

Ayhan H, Özel A 2017. Harran Ovası Koşullarında Dereotu (Anethum graveolens L.)'nda Uygun Hasat Zamanının Belirlenmesi, Harran Tarım ve Gida Bilimleri Dergisi 21(4): 466-479.

Bhuiyan MDNI, Begum J, Sultana M 2009. Chemical composition of leaf and seed essential oil of Coriandrum sativum L. from Bangladesh, Bangladesh J Pharmacol 4: 150-153.

Bowes KM, Zheljazkov VD 2005. Essential Oil Yields and Quality of Fennel Grown in Nova Scotia, Hortscience 39(7): 1640-1643.

Charles DJ, Simon JE, Widrlechner MP 1995. Characterization of Essential Oil of Dill (Anethum graveolens L.), Journal of Essential Oil Research 7(1): 11-20.
European Pharmacopoeia 7th Edition 2011. Council of Europe, Strasbourg, France.

Gohari AR, Saeidnia S 2011. A Review on Phytochemistry of Cuminum cyminum seeds and its Standards from Field to Market, Pharmacognosy Journal 3(25): 1-5.

Gotmare SR, Tambe EA 2018. Chemical Characterization of Cumin Seed Oil (Cuminum cyminum) by GC-MS and its Comparative Study, International Journal of Scientific Research in Biological Sciences 5(3): 36-45.

Gökduman GA, Telci İ 2018. Bazı Kişniş (Coriandrum sativum L.) Genotiplerinin Isparta Koşullarında Verim ve Kalite Özelliklerinin Belirlenmesi, Süleyman Demirel Üniversitesi Fen Bilimleri Enstitüsü Dergisi 22(3): 1165-1168.

Gruenwald J, Brendler T, Jaenicke C 2004. PDR for Herbal Medicines, 3rd Ed. Montvale, NJ: Thomson Healthcare, Londra. 700 sy.

Hah SA, Ea Ö 2016. Essential Oil Content and Chemical Composition of Eight Dill (Anethum Graveolens L.) Cultivars Cultivated under Egyptian Conditions, International Journal of Pharmacy and Pharmaceutical Sciences 8(5): 227231.

Haşimi N, Tolan V, Kızıl S, Kılınç E 2014. Anason (Pimpinella anisum L.) ve Kimyon (Cuminum cyminum L.) Tohumlarının Uçucu Yağ Kompozisyonu ile Antimikrobiyal ve Antioksidan Özelliklerinin Belirlenmesi, Tar. Bil. Der 20: 1926.

Hajyzadeh M, Yıldırım MU, Karagöz İ, Sarıhan EO, Khawar KM 2017. Farkl Yaşlardaki Anason (Pimpinella anisum L.) Tohumlarının Cimlenmesine Gibberellik Asitin ( $\left.\mathrm{GA}_{3}\right)$ Etkisi, KSÜ Doğa Bil. Dergisi (Özel Sayı) 20: 332-336.

Kaçar O, Özkan N 2005. Çeşitli İklim Faktörlerinin, Farklı Gelişme Dönemlerinin ve Gün İçerisindeki Farklı Toplama Saatlerinin Sarı Kantaron (Hypericum perforatum L.)'da Hiperisin Oranı Üzerine Etkisinin Belirlenmesi, Ege Üniv. Ziraat Fak. Dergisi 42(2): 23-34. 
Kan Y, Kartal M, Özek T, Aslan S, Başer KHC 2007. Composition of Essential Oil of Cuminum Cyminum L. According to Harvesting Times, Turkish J. Pharm. Sci. 4(1): 25-29.

Keskin S, Baydar H 2016. Umbelliferae Familyasından Bazı Önemli Kültür Türlerinin Isparta Ekolojik Koşullarında Tarımsal ve Teknolojik Özelliklerinin Belirlenmesi, S.D.Ü. Fen Bilimleri Enstitüsü Dergisi 20(1): 133-141.

Negahban M, Saeedfar S, Rowshan V, Najafian S 2015. Essential Oil Content and Composition of Fennel Fruits (Foeniculum vulgare Mill.), Russian Journal of Biological Research 4(2): 81-84.

Niamah AK, Alali HA 2016. Antibacterial and antioxidant activities of essential oils extracted from Iraqi coriander (Coriandrum sativum L.) seeds, International Journal of Scientific \& Engineering Research 7(2): 1511-1515.

Omidbaigi R, Hadjiakhoondi A, Saharkhiz M 2003. Changes in Content and Chemical Composition of Pimpinella anisum Oil at Various Harvest Time, Journal of Essential Oil Bearing Plants 6(1): 4650.

Orav A, Arak E, Ain R 2010. Essential Oil Composition of Coriandrum sativum L. Fruits from Different Countries, Journal of Essential Oil Bearing Plant 14(1): 118-123.

Orhan IE, Senol FS, Ozturk N, Celik SA, Pulur A, Kan Y 2013. Phytochemical contents and enzyme inhibitory and antioxidant properties of Anethum graveolens L. (dill) samples cultivated under organic and conventional agricultural conditions, Food Chemical Toxicology 59: 96-103.

Özel A 2000. Harran Ovası Koşullarında Kıvırcık Nane (Mentha spicata L.)'de Farklı Biçim Zamanlarinın Drog Verimi ve Bazı Kalite Kriterlerine Etkisi. Harran Üni. Ziraat Fakültesi Dergisi 4(1-2): 45-56.

Özkan F, Gürbüz B 2000. Tatll Rezene (Foeniculum vulgare Mill. var. dulce) 'de Bitki Siklığının Verim ve Verim Özellikleri Üzerine Etkileri. Tarla Bitkileri Merkez Araştırma Enstitüsü Dergisi 9: 12.

Raal A, Orav A, Arak E 2012. Essential oil composition of Foeniculum vulgare Mill. fruits from pharmacies in different countries, Natural Product Research 26(13): 1173-1178.

Rădulescu V, Popescu ÖL, Ilıeş DC 2010. Chemical Composition of The Volatile Oil from Different Plant Parts of Anethum graveolens L. (Umbelliferae) Cultivated in Romania, Farmacia 58(5): 594-600.

Rana VR 2014. Chemical Composition of the Essential Oil of Cuminum cyminum L. Seeds from Western India, Journal of Medicinal Plants and by-products 2: 207-210.

Rebey IB, Rahalı FZ, Tounsı MS, Marzouk B, Ksourı
$\mathrm{R}$ 2016. Variation in fatty acid and essential oil composition of sweet fennel (Foeniculum vulgare Mill) seeds as affected by salinity, Journal of New Sciences, Agriculture and Biotechnology 6: 12331240.

Saibi S, Belhadj M, Benyoussef EH 2013. Essential Oil Composition of Pimpinella anisum from Algeria, Analytical Chemistry Letters 2(6): 401404.

Shahat AA, Ibrahim AY, Hendawy SF, Omer EA, Hammouda FM, Abdel-Rahman FH, Saleh MA 2011. Chemical Composition, Antimicrobial and Antioxidant Activities of Essential Oils from Organically Cultivated Fennel Cultivars, Molecules 16: 1366-1377.

Shojaii A, Fard MA 2012. Review of Pharmacological Properties and Chemical Constituents of Pimpinella anisum, International Scholarly Research Pharmaceutics 2: 1-8.

Singh A, Randhawa GS 1991. Effect of CulturalPractices on Periodic Plant Height and Seed Yield of Dill (Anethum graveolens L.). Indian Journal of Agronomy 36(4): 574-577.

Stanojević LP, Stanković MZ, Cvetković DJ, Danilović BR, Stanojević JS 2016. Dill (Anethum graveolens L.) seeds essential oil as a potential natural antioxidant and antimicrobial agent, Brologica Nyssana 7(1): 31-39.

Şanlı A, Karadoğan T, Daldal H 2012. Burdur'da Tarımı Yapılan Bazı Umbelliferae Türlerinin Uçucu Yağ Oranı ve Bileşenlerinin Belirlenmesi, S.D.Ü.Z.F. Dergisi 7(1): 27-31.

Uyanık M 2013. Oğulotu (Melissa officinalis L.)'nda Ontogenetik, Morfogenetik ve Diurnal Varyabilitenin Ankara Koşullarında Belirlenmesi. Yüksek Lisans Tezi, Ankara Üniversitesi, Fen Bilimleri Enstitüsü Tarla Bitkileri Anabilim Dalı, Yüksek Lisans Tezi, 55 sy.

Uzun A, Kevseroğlu K, Yılmaz S 2011. Orta Karadeniz Bölgesi için Geliştirilen Rezene (Foeniculum vulgare Mill. var. dulce) Hatlarının Bazı Tarımsal Özellikler Bakımından İncelenmesi. Gaziosmanpaşa Üni. Ziraat Fakültesi Dergisi 28(2): 1-8.

Tian J, Ban X, Zeng H, Huang B, Wang Y 2011. In vitro and in vivo activity of essential oil from dill (Anethum graveolens L.) against fungal spoilage of cherry tomatoes, Food Control 22 (11): 1992-1999.

Zheljazkov VD, Astatkie T, O'Brocki B, Jeliazkova E 2013b. Essential Oil Composition and Yield of Anise from Different Distillation Times, Hortscience 48(11): 1393-1396.

Zheljazkov VD, Horgan T, Astatkie T, Schlegel V 2013a. Distillation Time Modifies Essential Oil Yield, Composition, and Antioxidant Capacity of Fennel (Foeniculum vulgare Mill), Journal of Oleo Science 62(9): 665-672. 